\title{
Studies of persistent infection by Chlamydia trachomatis serovar $K$ in TPA-differentiated U937 cells and the role of IFN- $\gamma$
}

\author{
E. NETTELNBREKER, H. ZEIDLER, H. BARTELS*, U. DRESES-WERRINGLOER, W. DÄUBENER†, \\ H. HOLTMANN $\ddagger$ and L. KÖHLER
}

Division of Rheumatology, * Laboratory of Cell Biology and Electron Microscopy, Medical School, Hannover, $\uparrow$ Division of Medical Microbiology and Virology, Heinrich-Heine-University, Düsseldorf and $¥$ Division of Molecular Pharmacology, Medical School, Hannover, Germany

\begin{abstract}
Inoculation of phorbol ester-differentiated U937 cells as a model for human macrophages with Chlamydia trachomatis of the urogenital serovar $K$ resulted in a persistent infection, with maximal growth at day 7 , until day 10 post-infection. At these times inclusion bodies were present in $0.5-2 \%$ of the cells. Typical inclusion bodies containing elementary bodies and reticulate bodies were observed by electron microscopy. Furthermore, single chlamydial particles resembling atypical elementary or intermediate bodies were identified in the cytoplasm in $>80 \%$ of the host cells. IFN- $\gamma$ exerts antichlamydial activity in epithelial and fibroblastoid cells, but the infection of U937 cells by $C$. trachomatis was not affected by IFN- $\gamma$. The activity of the tryptophandegrading enzyme indoleamine 2,3-dioxygenase (IDO) was not detected in untreated or in IFN- $\gamma$-treated or chlamydiae-infected or mock-infected U937 cells. The presence of atypical persisting chlamydiae and the lack of IDO expression in U937 cells indicates that the development of these atypical bacteria is independent from IFN- $\gamma$-mediated tryptophan deprivation and other IFN- $\gamma$-mediated effects. Evaluation of persistently infected cells revealed that the expression of the chlamydial major outer-membrane protein, heat-shock protein (hsp60) and lipopolysaccharide (LPS) antigens was not significantly altered in the course of the culture. An intense staining of the LPS on the surface of the host cells was demonstrated by immunofluorescence. The data show that phorbol ester-differentiated $\mathbf{U 9 3 7}$ cells restrict chlamydial growth strongly but not completely through a mechanism distinct from IDO-mediated tryptophan deprivation. The mechanisms of persistence of chlamydiae in monocytes, which differ considerably from those described for other cells, require further investigation.
\end{abstract}

\section{Introduction}

The obligate intracellular bacterium Chlamydia trachomatis exhibits a complex developmental cycle involving an infectious metabolically inactive form (elementary body: EB) and a non-infectious metabolically active form (reticulate body: RB) [1]. One characteristic of the biovar trachoma is its capacity to induce chronic diseases such as blinding trachoma or after urogenital infection - complications like infertility or ectopic pregnancy [2-4]. Moreover, C. trachomatis of the serovars $\mathrm{D}-\mathrm{K}$ have also been implicated in Reiter's disease and chlamydia-induced arthritis [5, 6].

Received 15 Oct. 1996; revised version accepted 13 June 1997.

Corresponding author: Dr L. Köhler.
The pathogenesis of the extra-urogenital chronic sequelae of chlamydial infections is not well understood. One important observation is that $C$. trachomatis persists at the site of inflammation in a viable but culture-negative state [7,8]. Chlamydial antigen has been detected in specimens from patients with active trachoma, even though chlamydiae could not be isolated by culture [9]. Chlamydia major outer membrane protein (MOMP), lipopolysaccharide (LPS) and rRNA have been identified in culturenegative specimens from inflamed joints of patients with chlamydia-induced arthritis and Reiter's syndrome [5,10-12]. Although the target cells for the trachoma biovar are preferentially mucosal epithelial cells, published data show the persistence of chlamydiae in monocytic cells [13-15]. Recently, Nanagara et al. demonstrated chlamydiae in both macrophages and fibroblasts from synovial membranes from patients 
with Reiter's disease some 12 years after the onset of the disease [8]. These observations suggest that persistent infection of monocytes may be relevant for the pathogenic process leading to chronic chlamydiainduced inflammatory disease.

An earlier study showed that morphologically altered but metabolically active $C$. trachomatis serotype $\mathrm{K}$ persists in human peripheral blood monocytes for 14 days post-infection in vitro $[13,16]$. The in-vitro infection of monocytes possibly reflects one basic mechanism of chronic chlamydial inflammation at the cellular level. However, the use of these cells to investigate the basic intracellular events in chlamydiamediated persistence has several limitations. The methods of preparation and separation do not exclude contamination with lymphocytes, only a limited number of cells can be obtained from one blood donor, and monocytes may vary according to the biological variability of the blood donors. The establishment of an in-vitro infection model with monocytic phorbol ester-treated U937 cells could therefore serve as an alternative tool to study the mechanisms of chlamydial persistence [17].

The aim of this study was to investigate the fate of $C$. trachomatis serovar $\mathrm{K}$ in differentiated U937 cells and the influence of IFN- $\gamma$. This cytokine induces persistence of chlamydiae in fibroblasts and epithelial cells [18-20]. Because persistent chlamydial infections have been proposed as a source of antigens that induces or maintains the chronic inflammatory diseases or both, the levels of chlamydial immunogens were evaluated during the course of chlamydial infection of U937 cells [21, 22].

\section{Materials and methods}

\section{Preparation of bacteria}

C. trachomatis serovar $\mathrm{K}(\mathrm{UW} / 31 / \mathrm{Cx}$; Washington Research Foundation, Seattle, USA) was grown in HEp-2 cells in complete medium RPMI 1640 supplemented with heat-inactivated fetal calf serum (Gibco) $10 \%, 2 \mathrm{mM}$ L-glutamine, vancomycin $25 \mathrm{mg} / \mathrm{L}$, gentamicin $5 \mathrm{mg} / \mathrm{L}$, glucose $1 \% \mathrm{w} / \mathrm{v}$ and cycloheximide $1 \mu \mathrm{g} / \mathrm{ml}$ (i.e. infection medium). Infected cells were harvested after culture for $48 \mathrm{~h}$ at $37^{\circ} \mathrm{C}$. EB were purified in a discontinuous gradient of Urographin [23] and stored in $100 \mu \mathrm{l}$ volumes at $-80^{\circ} \mathrm{C}$.

\section{Culture of cells and infection with C. trachomatis}

U937 cells from the American Type Culture Collection (Rockville, MD, USA) were cultured in RPMI 1640 medium with fetal calf serum 10\%, $2 \mathrm{mM}$ L-glutamine, vancomycin $25 \mathrm{mg} / \mathrm{L}$ and gentamicin $5 \mathrm{mg} / \mathrm{L}$ (i.e. culture medium) at $37^{\circ} \mathrm{C}$ in a humidified atmosphere with $\mathrm{CO}_{2} 5 \%$.
U937 cells were plated at a density of $1 \times 10^{6} /$ cells per well in six-well culture plates and differentiation was induced by adding the phorbol ester 12-Otetradecanoyl phorbol-13-acetate (TPA) $\left(5 \times 10^{-9} \mathrm{M}\right)$ to the culture medium. After $72 \mathrm{~h}$, the differentiated cells were washed once and inoculated with $C$. trachomatis at a multiplicity of infection (MOI) of 0.5 . Non-infected controls were run in parallel. After centrifugation $(20 \mathrm{~min}, 450 \mathrm{~g})$, the cells were incubated for $2 \mathrm{~h}$ at $37^{\circ} \mathrm{C}$ in $\mathrm{CO}_{2} 5 \%$ and then washed three times with Hanks's Balanced Salts Solution (HBSS) to remove non-ingested bacteria. At various times, cells were harvested by scraping with a rubber scraper and frozen at $-80^{\circ} \mathrm{C}$ for determinations of infectivity and chlamydial rRNA; preparations for immunofluorescence microscopy were made on the day of harvest. As positive controls for chlamydial infectivity, cultures of HEp- 2 cells $\left(5 \times 10^{5} / \mathrm{ml}\right)$ were infected and harvested as described above.

\section{IFN- $\gamma$ treatment of infected U937 culture}

Differentiated U937 cells were incubated with IFN- $\gamma$ at $25(1.25 \mathrm{ng})$ and $400(20 \mathrm{ng}) \mathrm{U} / \mathrm{ml}\left(1 \times 10^{6} \mathrm{U} \cong\right.$ $50 \mu \mathrm{g}$, Biogen) for $24 \mathrm{~h}$. Thereafter, the cells were infected with $C$. trachomatis and harvested at day 2 post-infection to determine infectivity and the number of inclusions. Treatment of HEp- 2 cells with IFN- $\gamma$ at $0.1-400 \mathrm{U} / \mathrm{ml}$ and subsequent infection with $C$. trachomatis (MOI 0.5) was performed as a control.

\section{Assay for intracellular IDO activity}

TPA-differentiated U937 cells were treated with or without IFN- $\gamma$ and with or without $C$. trachomatis and harvested 2, 3 and 5 days after infection. After washing in PBS, the pellets $\left(1 \times 10^{6}\right.$ cells $)$ were frozen at $-70^{\circ} \mathrm{C}$. The cell pellets were then thawed and the assay for indoleamine 2,3-deoxygenase (IDO) was performed as described previously [24]. The assay is based on the determination of the decyclisation product of $\mathrm{L}$ tryptophan, kynurenine, that is measured at an absorbance of $490 \mathrm{~nm}$ after addition of Ehrlich's reagent $\quad(0.4 \% \quad p$-dimethylaminobenzaldehyde/acetic acid). As a positive control IFN- $\gamma$-stimulated $86 \mathrm{HG} 39$ cells (glioblastoma cell line) were used. A strong IDO activation was found in these cells. They produced $>30 \mu \mathrm{g}$ of kynurenine/ $1 \times 10^{6}$ cells.

\section{Determination of the infectious yield of C. trachomatis}

The infectious yield of $C$. trachomatis was determined by titration on HEp-2 cells [25]. Frozen samples of infected TPA-differentiated U937 cells were thawed in an ice-bath and subsequently sonicated for $2 \mathrm{~min}$ (Transsonic 460; Merck, Germany); 50- $\mu$ l volumes of 10 -fold dilutions in infection medium were added to the HEp-2 cells growing in 96-well microtitration 
plates. After incubation for $48 \mathrm{~h}$ at $37^{\circ} \mathrm{C}$, the cultures were fixed with absolute ethanol. Inclusion bodies were stained by an immunoperoxidase assay, with the serum of a $C$. trachomatis-positive patient having an IgG specific titre of $>256$ (Ipazymtest, Medac, Hamburg, Germany), and counted by light microscopy. The results are expressed as infection forming units (IFU) $/ \mathrm{ml}$.

\section{Immunofluorescence microscopy}

For the direct immunofluorescence microscopy, infected and mock-infected U937 cells $\left(10^{5} / 100 \mu \mathrm{l}\right)$ were centrifuged on to slides and fixed with methanol. Chlamydial inclusion bodies and single bacteria were visualised with an anti-MOMP FITC-conjugated monoclonal antibody (MAb) (Syva, Palo Alto, CA, USA). Brightly shining green inclusions were counted and the results were expressed as inclusion bodies $/ 10^{5}$ cells. For the indirect immunofluorescence assay, TPAdifferentiation of U937 cells was performed on coverslips and cells were infected as described. At different times cultures were air-dried or fixed with methanol and subsequently treated with either the anti-hsp60 MAb GP 51-19 (a generous gift from Dr Morrison, Hamilton, MT, USA) or the anti-LPS MAb S 25-23 (a generous gift from Dr Brade, Borstel, Germany). Bound antibodies were visualised with a second FITC-labelled goat anti-mouse $\mathrm{F}\left(\mathrm{ab}^{\prime}\right)_{2}$ fragment (Dianova, Hamburg, Germany). All samples were screened with an epifluorescence microscope (Leitz, Wetzlar, Germany).

\section{Determination of chlamydial rRNA synthesis}

Chlamydial rRNA was determined by an in-vitro hybridisation assay with a single-stranded chemiluminescent-labelled cDNA probe (PACE 2; Gen-probe, San Diego, CA, USA). Samples of infected U937 cells $\left(1-3 \times 10^{5}\right)$ were resuspended in $100 \mu \mathrm{l}$ of lysis buffer (Gen-probe) and the test was performed according to the manufacturer's instructions. Concentrations of chlamydial rRNA are expressed as relative light units (RLU). In our experience, the test has a detection limit of rRNA corresponding to 50 IFU [12].

\section{Transmission electron microscopy}

Pellets of TPA-differentiated U937 cells $\left(2 \times 10^{6}\right.$ cells $/$ pellet) infected with $C$. trachomatis were harvested at day 7 after infection and fixed in glutaraldehyde $3 \%$ in $0.1 \mathrm{M} \mathrm{Na}$-cacodylate $\mathrm{HCl}$ buffer, $\mathrm{pH} 7.3$, for $1 \mathrm{~h}$, postfixed in $\mathrm{OsO}_{4} 2 \%$ in the same buffer, dehydrated in a graded series of ethanol and embedded in AgarAraldite. Thin sections were stained with uranyl acetate and lead citrate and examined in a Siemens Elmiskop IA electron microscope at $80 \mathrm{KV}$. Mock-infected U937 cells served as negative controls.

\section{Immunoblot assay}

TPA-differentiated U937 cells were infected in six-well culture plates and harvested at the times indicated, centrifuged and resuspended in $100 \mu \mathrm{l}$ of PBS. After sonication, the concentration of protein in the samples was determined by a micro-Bradford assay with bovine serum albumin as a standard protein. Equal amounts of protein were denatured in SDS 6\%, glycerol 30\% and $\beta$-mercaptoethanol $15 \%$ in $0.0625 \mathrm{M}$ Tris and resolved by SDS-PAGE (acrylamide $10 \%$ gel) as described by Laemmli [26]. Lysates of isolated EBs served as the positive control. After electrophoresis, the separated proteins were transferred to PVDF membranes (Immobilon-P, Millipore, Bedford, MA, USA). Nonspecific binding sites were blocked by incubation in blocking buffer (PBS, Tween $200.05 \%$, milk 5\%). The blot was probed with either the murine GP51-19 MAb directed against the chlamydial hsp60 or the mouse anti-MOMP MAb LV 22 (Washington Research Foundation) or the mouse anti-LPS MAb [27, 28]. Immunopositive proteins were visualised with alkaline phophatase-conjugated rabbit anti-mouse IgG (Dianova) followed by staining with 5-bromo-4-chloro-3indolyl phosphate (BCIP) and nitrobluetetrazolium (NBT; both from Sigma). Lanes were analysed with a scanning densitometer (Pharmacia, Freiburg, Germany).

\section{Statistical analysis}

Statistical analysis was performed on the mean and SD of independent experiments. The significance of the values was calculated with the non-paired two-tailed Student's $t$ test. A $\mathrm{p}$ value $<0.05$ was considered to indicate a significant difference between two sets of data.

\section{Results}

\section{Infection of U937 cells with C. trachomatis}

The fate of C. trachomatis in TPA-differentiated U937 cells was investigated over 14 days. The infection was followed by determination of chlamydial inclusion bodies by immunofluorescence, by titration of cell lysates from infected U937 cells on HEp-2 cells and by measurement of chlamydial rRNA. Cells inoculated with $C$. trachomatis at an MOI of 0.5 permitted low grade replication over the whole cultivation period without destroying the cell culture (Fig. 1a-c). The number of fluorescent inclusion bodies stained with the anti-MOMP MAb increased gradually from the day of infection to day 7 after infection (Fig. 1a). An additional significant rise in the yield of inclusions was found between day 7 and day 10 after infection $(p<0.001)$. At that time, $0.5-2 \%$ of the TPAdifferentiated U937 cells contained fluorescent inclusions as shown in Fig. 2. Single fluorescent chlamydial particles were also observed in cells containing no inclusion bodies. From day 10 to day 14 after infection, 

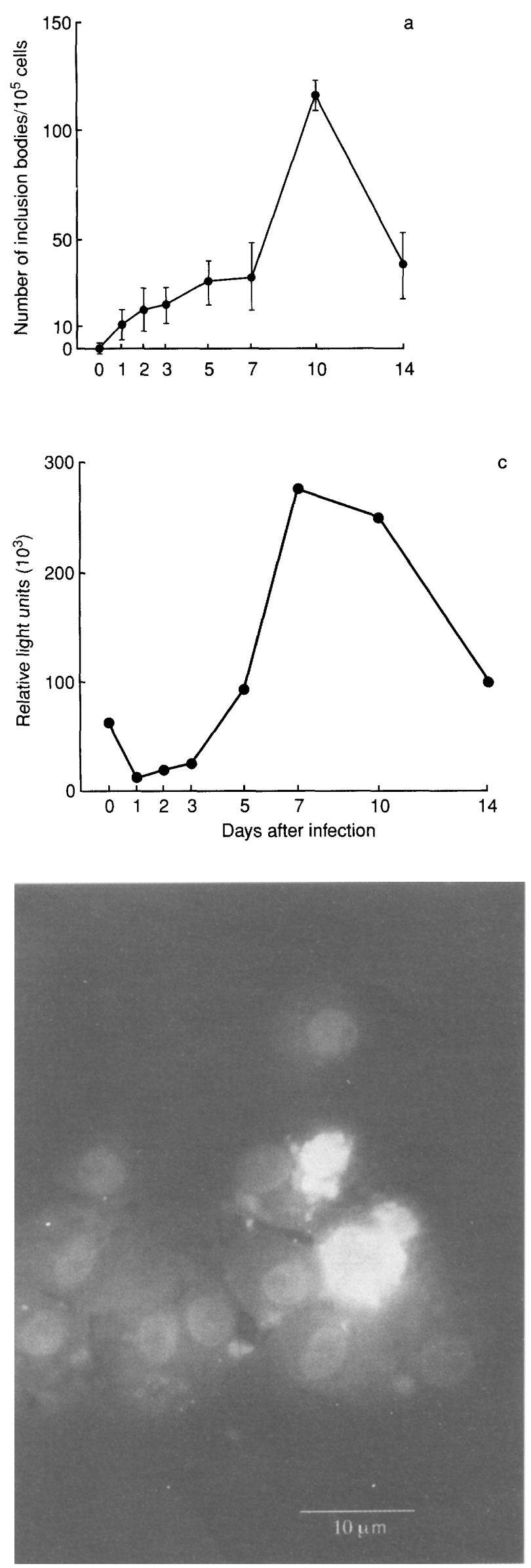

Fig. 2. Chlamydial inclusions stained with the fluorescent anti-MOMP antibody in TPA-differentiated U937 cells at day 7 after infection.

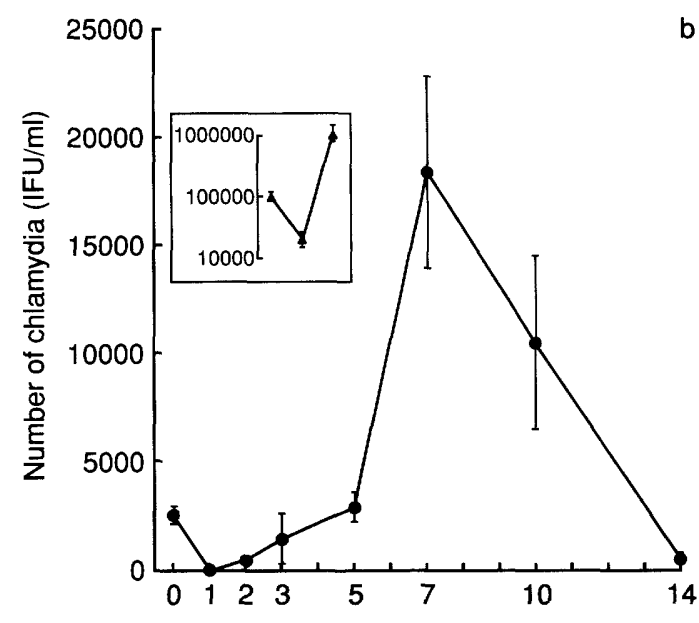

Fig. 1. (a) The number of inclusion bodies as determined by direct immunofluorescence in TPA-differentiated U937 cells at the indicated time points following infection with $C$. trachomatis serovar $\mathrm{K}$ at a $\mathrm{MOI}$ of 0.5. Data are the means and SD of four separate experiments, each performed in duplicate. (b) Infectious yield of $C$. trachomatis. Titration of the lysates from TPA-differentiated U937 cells at the indicated time points after infection with $C$. trachomatis at a MOI of 0.5 (O) on HEp-2 cells. Data are the means and SD of four separate experiments, each performed in duplicate. In control experiments (insert $\Delta$ ) the growth in HEp-2 cells infected with $C$. trachomatis at a MOI of 0.5 was determined. The yield of infective chlamydia is expressed as IFU $/ \mathrm{ml}$. (c) The kinetics of chlamydial rRNA synthesis in TPA-differentiated U937 cells after infection with $C$. trachomatis at a MOI of 0.5 . One representative experiment of four is shown.

the number of inclusions decreased considerably $(p<0.003)$. Coincident with the increase of inclusion bodies, a rise in the infectious yield of $C$. trachomatis was observed from day 1 to day 7 after infection $(p<0.004)$ and a decrease of infectivity was apparent from day 7 to day 14 after infection $(p<0.002)$ as determined by titration of the lysates from infected TPA-differentiated U937 cells on HEp-2 cells (Fig. 1b). In control (HEp-2) cells infected at an MOI of 0.5 , the yield of C. trachomatis was c. $2.3 \log _{10}$ higher than in infected U937 cells (Fig. 1b). In contrast to the U937 cells, the monolayer of HEp-2 cells was destroyed after culture for 3 days as observed by immunofluorescence and light microscopy. The amount of chlamydial rRNA that was determined in infected cultures of TPAdifferentiated U937 cells followed a similar time course to the infectivity (Fig. 1c).

\section{Effect of IFN- $\gamma$}

Pretreatment of chlamydiae-infected Hep-2 cells with IFN- $\gamma$ concentrations $>25 \mathrm{U} / \mathrm{ml}$ inhibited the development of infective elementary bodies as shown by titration of the cell lysates on HEp-2 cells, whereas lower concentrations of IFN- $\gamma$ still permitted infectivity (Table 1). Therefore, $25 \mathrm{U}$ of the cytokine $/ \mathrm{ml}$ were incubated with TPA-differentiated U937 cell $24 \mathrm{~h}$ before infection with C. trachomatis. As shown in Table 1, the 
Table 1. The effect of human IFN- $\gamma$ on the growth of $C$. trachomatis serovar $\mathrm{K}$ in HEp-2 cells or U937 cells

\begin{tabular}{lcc}
\hline & $\begin{array}{c}\text { Mean (SD) } \\
\text { number of } \\
\text { Cells and treatment }\end{array}$ & $\begin{array}{c}\text { Mean (SD) number } \\
\text { of IFU } / \mathrm{ml}\end{array}$ \\
\hline HEp-2 & & \\
Medium & $5000(430)$ & $800000(35000)$ \\
$\quad+$ IFN- $\gamma(0.1 \mathrm{U} / \mathrm{ml})$ & $1230(120)$ & $230000(10000)$ \\
+ IFN- $\gamma(10 \mathrm{U} / \mathrm{ml})$ & $70(10)$ & $216(22)$ \\
+ IFN- $\gamma(25 \mathrm{U} / \mathrm{ml})$ & $12(4)$ & 0 \\
+ IFN- $\gamma(100 \mathrm{U} / \mathrm{ml})$ & $7(3)$ & 0 \\
+ IFN- $\gamma(400 \mathrm{U} / \mathrm{ml})$ & $10(4)$ & 0 \\
U937 & $20(15)$ & $260(30)$ \\
Medium & $35(18)$ & $300(50)$ \\
+ IFN- $\gamma(25 \mathrm{U} / \mathrm{ml})$ & $23(12)$ & $250(45)$ \\
+ IFN- $\gamma(400 \mathrm{U} / \mathrm{ml})$ & &
\end{tabular}

HEp-2 cells and TPA-differentiated U937 cells were pretreated with or without IFN- $\gamma$ at concentrations indicated and infected with $C$. trachomatis serovar $\mathrm{K}$ for 2 days. The numbers of inclusions $/ 10^{5}$ cells and IFU $/ \mathrm{ml}$ were the mean (SD) of three experiments.

production of infectious chlamydiae and the development of inclusions in U937 cells was not altered by this concentration. Pre-incubation with IFN- $\gamma$ at $400 \mathrm{U} / \mathrm{ml}$ also did not result in a decrease in the number of IFU or fluorescent inclusion bodies.

IFN- $\gamma$ treatment has been shown to induce the expression of IDO, that converts L-tryptophan to kynurenine. It has been proposed that IFN-mediated chlamydial persistence arises from enhanced IDO expression and subsequent tryptophan depletion. However, this enzyme was not found to be induced in U937 cells by either IFN- $\gamma$ or chlamydiae or both together (data not shown), whereas in the positive control (IFN- $\gamma$-treated $86 \mathrm{HG} 39$ cells), strong IDO activity was measured.

\section{Electron microscopy}

Only few (1-2\%) of the TPA-differentiated U937 cells that were examined 7 days after incubation with $C$. trachomatis at a MOI of 0.5 contained a typical inclusion body with numerous $\mathrm{EB}, \mathrm{RB}$ and intermediate forms (Fig. 3a). However, $>80 \%$ of the U937 cells contained vacuoles in which one or two chlamydiae were present. The bacteria within the vacuoles often had an enlarged shape containing electron-dense material and resembled EB or intermediate forms but not RB (Fig. 3b). In mock-infected U937 cells, no such structures were observed.

\section{Expression of chlamydial antigens}

To determine levels of chlamydial antigens during persistent infection of U937 cells, three were selected for evaluation: the MOMP antigen, a target of neutralising antibodies (the major vaccine antigen); LPS, a major antigen on the chlamydial surface; and the hsp60 antigen, chosen because the immune response to this protein may be important in the immunopathogenesis of persistent inflammation [22, 29-31]. Immunoblotting and immunofluorescence were used to compare the amounts and localisation of MOMP, LPS and hsp60 in infected U937 cells. Densitometer tracings of immunoblots of cells $48 \mathrm{~h}$ after infection indicated a $6.5: 1$ ratio of hsp60 to MOMP (Fig. 4, lane A) and a nearly 8.6:1 ratio of hsp60 to MOMP (Fig. 4, lanes C, D, E) in cells 7, 10 and 14 days after infection. The 5.7:1 ratio of hsp60 to MOMP in isolated elementary bodies corresponds to the ratio in infected cells $48 \mathrm{~h}$ after infection. The level of the chlamydial LPS slightly increased during infection of U937 cells.

Immunofluorescence with the anti-LPS MAb gave an intense staining on the surface of the air-dried U937 cells at every time-point of the culture, whereas the anti-hsp60 MAb stained only the inclusions in the airdried cells (Fig. 5a, b). In infected U937 cells that were fixed with methanol, only chlamydial inclusions were stained with the anti-LPS MAb or with the antihsp60 MAb (not shown). No staining was observed with either mock-infected U937 cells or the second antibody alone.

\section{Discussion}

Persistent infection by $C$. trachomatis has been studied in a limited number of cell culture systems and most experiments have been performed in fibroblasts or epithelial cells $[20,21,32]$. However, these cells are not the only important host cells in vivo, because increasing evidence shows that 'professional' phagocytes play a decisive role in the persistence of chronic chlamydial infections $[13,14,33]$. It has been proposed that monocytes act as vehicles for chlamydial dissemination in the infected host and serve as reservoirs of antigens that trigger the inflammatory response [3436]. A persistent infection of C. trachomatis was established in the monocytic cell line U937 under nonlimiting growth conditions, i.e., in the absence of inhibitors or deficiencies. This cell culture system differs from the established host-parasite system with biphasic cycles of McCoy cells and C. trachomatis introduced by Lee and Moulder [32]. The present study showed that TPA-differentiated U937 cells became persistently infected after inoculation at a low and nondestructive MOI with the chlamydial urogenital strain serovar K. Clearly the transition from infected host cells to new host cells was low and, therefore, over a period of 14 days a co-existence or balance between chlamydial development and intact live cell culture was maintained. It is important to note that only $0.5-2 \%$ of the U937 cells contained inclusion bodies at the time when chlamydial infectivity and replication were at a maximum, i.e. day 7 until day 10 after infection. However, $>80 \%$ of these cells contained chlamydiae differing in ultrastructure from the typical $E B$ and $R B$ present in inclusion bodies. This observation may explain the observation of single fluorescent particles by immunofluorescence microscopy. The atypical EB- 

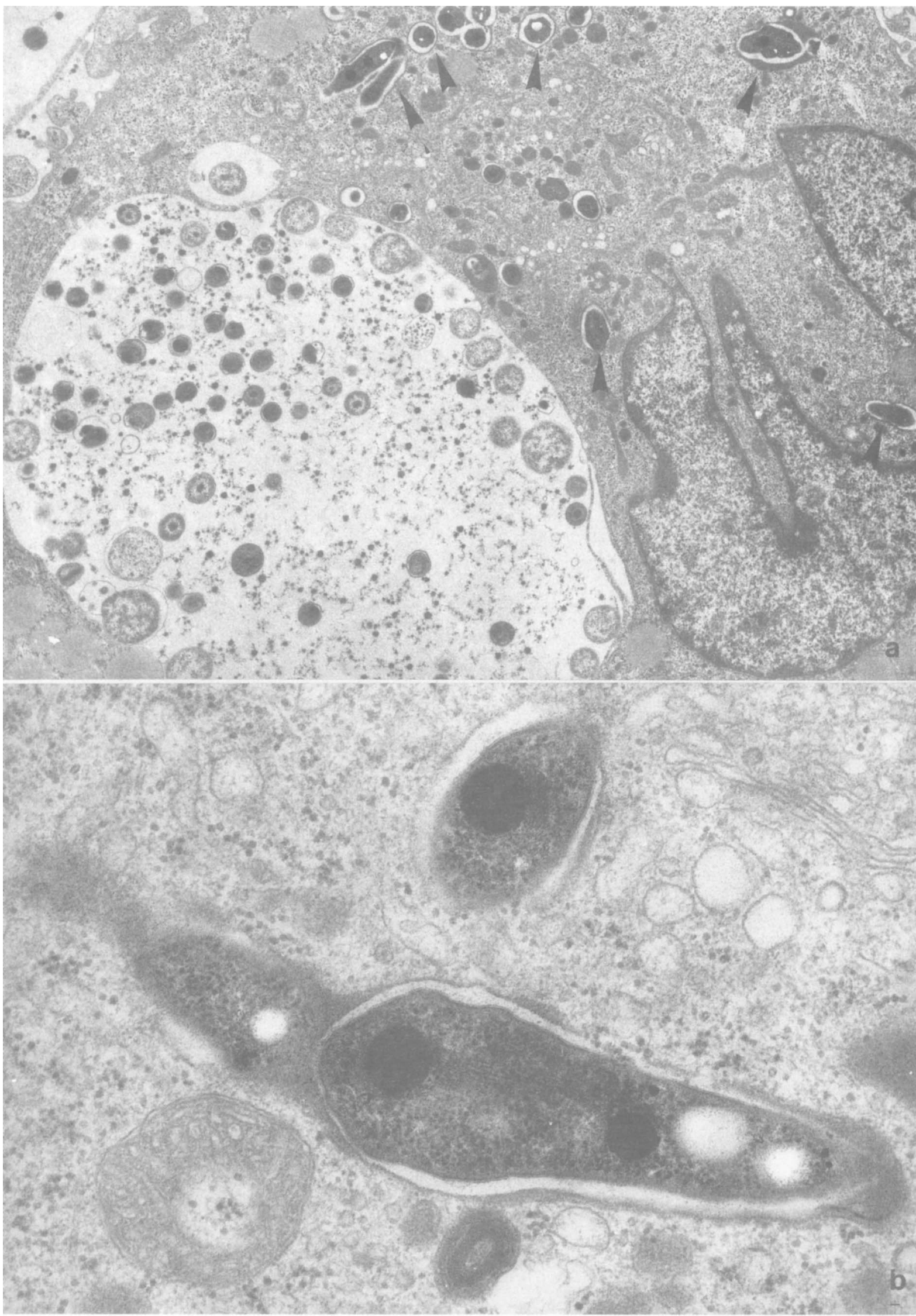

Fig. 3. Transmission electron micrographs of TPA-differentiated U937 cells 7 days after infection with $C$. trachomatis a: U937 cell with an inclusion body containing typical elementary bodies, reticulate bodies and intermediate forms; arrows point to a single $C$. trachomatis in the cytoplasm (magnification $\times 10000$ ). b: Magnification of an intracellular phagosome containing atypical chlamydiae (magnification $\times 60000)$. 


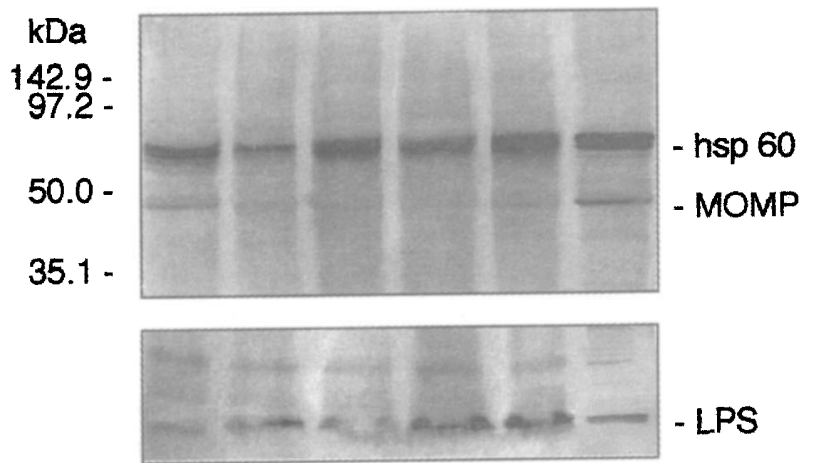

A $B$ C $\quad D \quad$ E $F$

Fig. 4. Immunoblot analysis of TPA-differentiated U937 cells infected at a MOI of 1 with $C$. trachomatis serovar $\mathrm{K}$. Blots were treated with anti-hsp60, anti-MOMP and anti-LPS antibodies. Lanes, A-E represent day 2 (A), day 5 (B), day 7 (C), day 10 (D) and day 14 (E). Lane $\mathbf{F}$ shows reactivity for isolated elementary bodies as control. like or intermediate bodies resemble those described in human monocytes infected with serovar L2 [34]. Furthermore, a recent electron microscopy and immuno-electronmicroscopy study showed that atypical chlamydiae of serovar $\mathrm{K}$ are present in human monocytes during non-replicative infection [16]. These organisms are in a metabolically active state as demonstrated by molecular analyses of primary chlamydial rRNA transcripts [16] and look very similar to those found in U937 cells harvested at day 7 after infection.

Significant differences were noted in the ability of $C$. trachomatis serovar $\mathrm{K}$ to generate infectious $\mathrm{EB}$ in inclusion bodies in various cell types. Whereas inclusion bodies developed in only very few TPAtreated U937 cells they occurred in virtually all cells of HEp-2 cultures infected in parallel with the same preparation of chlamydiae and did not develop at all in human peripheral blood monocytes [13]. This
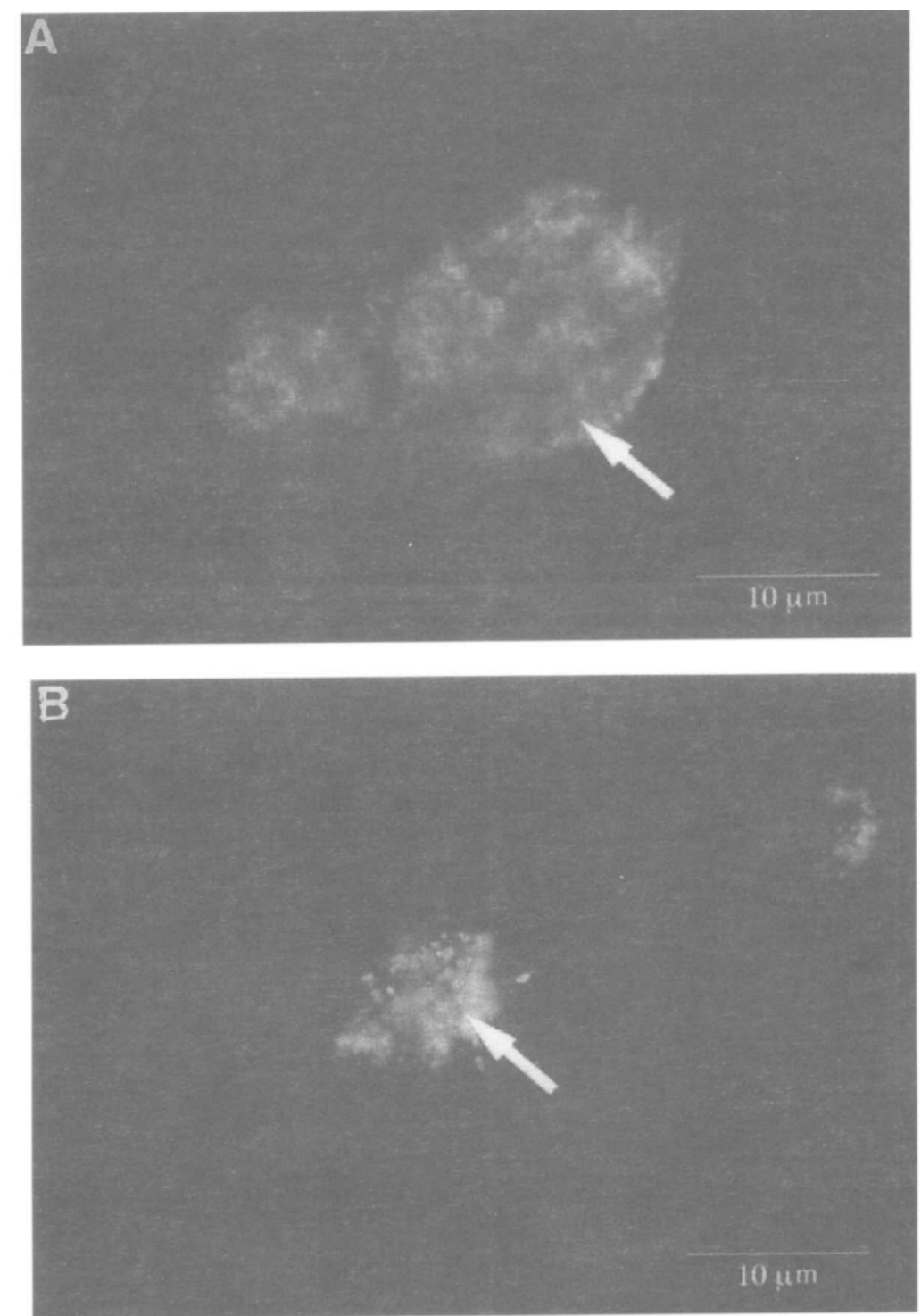

Fig. 5. TPA-differentiated U937 cells 7 days after infection with $C$. trachomatis. Cells were air-dried and stained by indirect immunofluorescence. LPS antibody (A) yielded a surface staining pattern of the U937 cells (arrow), whereas the hsp60 antibody (B) stained the inclusion in the host cell (arrow). 
observation indicates that, depending on the host cell, the replication of chlamydiae is permitted, retarded or inhibited.

In vivo, the intracellular pathogen is sheltered from direct immune attack, but it remains susceptible to the cytokine-mediated immune response. IFN- $\gamma$ has been proposed as a physiological mediator of chlamydial persistence, because it induces atypical, non-infectious chlamydiae in fibroblasts and epithelial cells in vitro. This persistent state is caused by IFN- $\gamma$-mediated induction of $\operatorname{IDO}[19,25,37-39]$. This enzyme catalyses the decyclisation of tryptophan in human cells. The depletion of this essential amino acid correlates with the growth inhibition of $C$. trachomatis in epithelial or fibroblastoid cells and addition of tryptophan was shown to reverse the inhibitory effect of IFN $-\gamma$ [39, 40]. No IFN- $\gamma$ mediated growth inhibition was observed in infected U937 cells although the cells were susceptible to the cytokine as shown previously. Exogenously added IFN- $\gamma$ specifically mediates the release of IL-1 $\beta$ [41]. The phenomenon of chlamydial growth in spite of IFN- $\gamma$ treatment can be explained by the fact that IDO is not active in these cells [42]. Even though the enzyme is not expressed, atypical organisms were detected in $80 \%$ of the U937 cells examined, indicating that tryptophan deficiency was not the cause of the development of these atypical forms. Moreover, in peripheral blood monocytes infected with serovar $\mathrm{K}$, the addition of tryptophan or antibodies against IFN- $\gamma$ did not result in the generation of replicative/infective organisms [16]. Thus, an unknown mechanism(s) exists that inhibits the growth cycle of phagocytosed chlamydiae in monocytic cells.

The intracellular persistence of $C$. trachomatis may possibly initiate and contribute to the maintenance of chronic inflammation. The chlamydial hsp60 antigen is considered to be a strong candidate responsible for the stimulation of the immune response [22]. IFN- $\gamma-$ mediated persistent infection in $\mathrm{HeLa}$ cells is characterised by a decreased expression of chlamydial MOMP and LPS, whereas the chlamydial hsp60 expression remains unchanged $[21,43]$. In lysates of persistently infected U937 cells an increase of hsp60 and LPS was observed whereas the level of MOMP did not alter from day 2 to day 14. The different antigen expression in these two persistence models may be explained by the developmental state of chlamydiae in both cell lines. Whereas in IFN- $\gamma-$ treated HeLa cells no infectious bacteria developed, in U937 cells low infectivity and the enhanced appearance of atypical bacteria resulted in the synthesis of hsp60 and LPS.

By immunofluorescence, the LPS antigen was not only shown in association with chlamydial development stages in inclusions, but was also stained on the surface of the infected U937 cells. These findings are in accordance with previous studies that have demonstrated extrachlamydial LPS on the surface of host cells $[44,45]$. Several investigators have reported that isolated LPS stimulates monocytes to produce the proinflammatory cytokines IL- $1 \beta$ and TNF- $\alpha$ [46, 47]. The observation of chlamydial LPS on the surface of the host cell and the well known induction of inflammatory cytokines in response to endotoxin suggest that LPS may play a profound role in the pathogenesis of chlamydial infections.

Chlamydial hsp60 antibody was kindly provided by Dr Morrison (National Institute of Allergy and Infectious Diseases, Hamilton, MT, USA) and the chlamydial LPS antibody by Dr Brade (Department of Biochemical Microbiology, Borstel, Germany). The data were presented in part at the Eighth International Symposium on Human Chlamydial Infections in June 1994, Couvieux Chantilly, France: Abstract number 198. This work was supported by the Deutsche Forschungsgemeinschaft, grant Ko 949/2-1 and grant Ko 949/2-2.

\section{References}

1. Ladany S, Sarov I. Recent advances in Chlamydia trachomatis. Eur J Epidemiol 1985; 1: 235-256.

2. Schachter J. Chlamydial infections. West J Med 1990; 153: 523-534.

3. Ward M, Bailey R, Lesley A, Kajbaf M, Robertson J, Mabey D. Persisting inapparent chlamydial infection in a trachoma endemic community in the Gambia. Scand J Infect Dis 1990; Suppl 69: 137-148.

4. Campbell LA, Patton DL, Moore DE, Cappuccio AL, Mueller BA, Wang SP. Detection of Chlamydia trachomatis deoxyribonucleic acid in women with tubal infertility. Fertil Steril 1993; 59: 49-50.

5. Keat A, Dixey J, Sonnex C, Thomas B, Osborn M, TaylorRobinson D. Chlamydia trachomatis and reactive arthritis: the missing link. Lancet 1987; 1: 72-74.

6. Wollenhaupt J, Zeidler H. Chlamydia-induced arthritis. EULAR Bulletin 1990; 3: 72-77.

7. Holland SM, Hudson AP, Bobo L et al. Demonstration of chlamydial RNA and DNA during a culture-negative state. Infect Immun 1992; 60: 2040-2047.

8. Nanagara R, Li F, Beutler A, Hudson A, Schumacher HR. Alteration of Chlamydia trachomatis biologic behavior in synovial membranes. Arthritis Rheum 1995; 38: 1410-1417.

9. Schachter J, Moncada J, Dawson CR et al. Nonculture methods for diagnosing chlamydial infection in patients with trachoma: a clue to pathogenesis of the disease? J Infect Dis 1988; 158: 1347-1352.

10. Mascia MT, Manzini CU, Manzini E. Chlamydia-induced arthritis. Immunofluorescent antibody studies of the synovial fluid from 4 patients. Clin Exp Rheumatol 1992; 10: 425-426.

11. Taylor-Robinson D, Gilroy CB, Thomas BJ, Keat ACS. Detection of Chlamydia trachomatis DNA in joints of reactive arthritis patients by polymerase chain reaction. Lancet 1992; 340: $81-82$.

12. Hammer M, Nettelnbreker E, Hopf S, Schmitz E, Pörschke K, Zeidler $H$. Chlamydial rRNA in the joints of patients with Chlamydia-induced arthritis and undifferentiated arthritis. Clin Exp Rheumatol 1992; 10: 63-66.

13. Schmitz E, Nettelnbreker E, Zeidler H, Hammer M, Manor E, Wollenhaupt J. Intracellular persistence of chlamydial major outer-membrane protein, lipopolysaccharide and ribosomal RNA after non-productive infection of human monocytes with Chlamydia trachomatis serovar K. J Med Microbiol 1993; 38: 278-285.

14. Ishikawa $\mathrm{H}$, Ohno $\mathrm{O}$, Yamasaki $\mathrm{K}$, Ikuta $\mathrm{S}$, Hirohata $\mathrm{K}$. Arthritis presumably caused by Chlamydia in Reiter's syndrome. Case report with electronmicroscopic studies. J Bone Joint Surg 1986; 68A: 777-779.

15. Koehler L, Nettelnbreker E, Ott N, Drommer W, Zeidler H. Persistent, non-productive infection of human peripheral blood monocytes with $C$. trachomatis is due to an intracellular growth 
arrest at an early stage of the chlamydial development. In Orfila J, Byrne G, Chernesky H (eds) Chlamydial infections. Società Edirice Esculapio, Bolognia. 1994: 427-430.

16. Koehler L, Nettelnbreker E, Hudson AP et al. Ultrastructural and molecular analyses of the persistence of Chlamydia trachomatis (serovar K) in human monocytes. Microb Pathog 1997; 22: 133-142.

17. Hass R, Bartels $\mathrm{H}$, Topley $\mathrm{N}$ et al. TPA-induced differentiation and adhesion of U937 cells: changes in ultrastructure, cytoskeletal organization and expression of cell surface antigens. Eur J Cell Biol 1989; 48: 282-293.

18. Byrne GI, Lahmann LK, Landry GJ. Induction of tryptophan catabolism is the mechanism for gamma-interferon-mediated inhibition of intracellular Chlamydia psittaci replication in T24 cells. Infect Immun 1986; 53: 347-351.

19. Beatty WL, Byrne GI, Morrison RP. Morphologic and antigenic characterization of interferon $\gamma$-mediated persistent Chlamydia trachomatis infection in vitro. Proc Natl Acad Sci USA 1993; 90: 3998-4002.

20. Thomas SM, Garrity LF, Brandt CR et al. IFN-gamma-mediated antimicrobial response. $J$ Immunol 1993; 150: 5529-5534.

21. Morrison RP, Belland RJ, Lyng K, Caldwell HD. Chlamydial disease pathogenesis. The $57-\mathrm{kD}$ chlamydial hypersensitivity antigen is a stress response protein. $J$ Exp Med 1989; 170: $1271-1283$.

22. Morrison RP, Lyng K, Caldwell HD. Chlamydial disease pathogenesis. Ocular hypersensitivity elicted by a genusspecific 57-kD protein. $J$ Exp Med 1989; 169: 663-675.

23. Caldwell HD, Kromhout J, Schachter J. Purification and partial characterization of the major outer membrane protein of Chlamydia trachomatis. Infect Immun 1981; 31: 1161-1176.

24. Däubener W, Wanagat N, Pilz K, Seghrouchni S, Fischer HG, Hadding U. A new, simple, bioassay for human IFN- $\gamma . J$ Immunol Methods 1994; 168: 39-47.

25. Shemer Y, Sarov I. Inhibition of growth of Chlamydia trachomatis by human gamma interferon. Infect Immun 1985; 48: $592-596$.

26. Laemmli UK. Cleavage of structural proteins during the assembly of the head of bacteriophage T4. Nature 1970; 227: $680-685$.

27. Yuan Y, Lyng K, Zhang Y-X, Rockey DD, Morrison RP. Monoclonal antibodies define genus-specific, species-specific, and cross-reactive epitopes of the chlamydial 60-kilodalton heat shock protein (hsp60): specific immunodetection and purification of chlamydial hsp60. Infect Immun 1992; 60: 2288-2296.

28. Fu Y, Baumann M, Kosma P, Brade L, Brade H. A synthetic glycoconjugate representing the genus-specific epitope of chlamydial lipopolysaccharide exhibits the same specificity as its natural counterpart. Infect Immun 1992; 60: 1314-1321.

29. Byrne G, Stephens RS, Ada G et al. Workshop on in vitro neutralization of Chlamydia trachomatis: summary of proceedings. $J$ Infect Dis 1993; 168: 415-420.

30. Brade L, Nurminen P, Mäkelä P, Brade H. Antigenic properities of Chlamydia trachomatis lipopolysaccharide. Infect Immun 1985; 48: 569-572.

31. Brunham RC, Peeling R, Maclean I, Kosseim ML, Paraskevas M. Chlamydia trachomatis-associated ectopic pregnancy: serologic and histologic correlates. J Infect Dis 1992; 165: 1076-1081.
32. Lee CK, Moulder JW. Persistent infection of mouse fibroblasts (McCoy cells) with a trachoma strain of Chlamydia trachomatis. Infect Immun 1981; 32: 822-829.

33. Schumacher HR, Magge S, Cherian PV et al. Light and electron microscopic studies on the synovial membrane in Reiter's syndrome. Immunocytochemical identification of chlamydial antigen in patients with early disease. Arthritis Rheum 1988; 31: 937-946.

34. Manor E, Sarov I. Fate of Chlamydia trachomatis in human monocytes and monocyte-derived macrophages. Infect Immun 1986; 54: $90-95$.

35. Sarov I, Geron E, Shemer-Avni $\mathrm{Y}$ et al. Implications for persistent chlamydial infections of phagocyte-microorganism interplay. Eur J Microbiol Infect Dis 1991; 10: 119-129.

36. Rothermel CD, Rubin BY, Murray HW. $\gamma$-interferon is the factor in lymphokine that activates human macrophages to inhibit intracellular Chlamydia psittaci replication. J Immunol 1983; 131: 2542-2544.

37. Byrne G. Interferons, immunity and Chlamydiae. In: Byrne GI, Turco, J (eds) Interferon and nonviral pathogens. New York, Marcel Dekker Inc. 1988: 73-94.

38. Rapoza P, Tahija SG, Carlin JP, Miller S, Padilla MP, Byrne GI. Effect of interferon on a primary conjuctival epithelial cell model of trachoma. Invest Ophthalmol Vis Sci 1991; 32: 2919-2923.

39. Beatty WL, Belanger TA, Desai AA, Morrison RP, Byrne GI Tryptophan depletion as a mechanism of gamma interferonmediated chlamydial persistence. Infect Immun 1994; 62: $3705-3711$.

40. Nettelnbreker E, Bonk C, Zeidler H, Köhler L. IFN- $\gamma$ mediated persistence of Chlamydia trachomatis serovar $\mathrm{K}$ is reversible with tryptophan in Hep-2 cells but not in monocytic THP-1 cells. In: Stany A (ed) Proceedings of the Third Meeting of the European Society for Chlamydia Research. Società Edirice Esculapio, Bolognia. 1996: 86.

41. Hass R, Lonnemann G, Männel D et al. Regulation of TNFalpha, IL-1 and IL-6 synthesis in differentiating human monoblastoid leukemic U937 cells. Leuk Res 1991; 15: 327 339.

42. Kiekenbeck M, Bange F-C, Vogel U, Däubener W, Böttger EC. Characteristics of interferon induced tryptophan metabolism in human macrophages in vitro. Immunobiology 1993; 189: 178.

43. Beatty WL, Morrison RP, Byme GI. Immunoelectron-microscopic quantitation of differential levels of chlamydial proteins in a cell culture model of persistent Chlamydia trachomatis infection. Infect Immun 1994; 62: 4059-4062.

44. Hearn SA, McNabb GL. Immunoelectron microscopic localization of chlamydial lipopolysaccharide (LPS) in McCoy cells inoculated with Chlamydia trachomatis. J Histochem Cytochem 1991; 39: 1067-1075.

45. Karimi ST, Schloemer RH, Wilde CE. Accumulation of chlamydial lipopolysaccharide antigen in the plasma membranes of infected cells. Infect Immun 1989; 57: 1780-1785.

46. Rothermel CD, Schachter J, Lavrich P, Lipsitz EC, Francus T. Chlamydia trachomatis-induced production of interleukin-1 by human monocytes. Infect Immun 1989; 57: 2705-2711.

47. Ingalls RR, Rice PA, Qureshi N, Takayama K, Lin JS, Golenbock DT. The inflammatory cytokine response to Chlamydia trachomatis infection is endotoxin mediated. Infect Immun 1995; 63: 3125-3130. 